\title{
THE BACKGROUND OF THE ROMANTIC MOVEMENT IN FRENCH MUSIC
}

\author{
By ARTHUR W. LOCKE
}

$I^{\mathrm{N}}$ $\mathrm{N}$ the revolution of feeling and thought which came at the end of the eighteenth and the beginning of the nineteenth centuries and which has been called "the romantic movement," French music took an active though belated part. It was not until the days of Hugo's Preface to Cromwell, with its romantic ultimatum, and of the first performances of his Ernani and Vigny's Chatterton, when, indeed, the storm of the romantic revolt burst with a fury which presaged the end, that the Fantastic Symphony of Berlioz gave French music as prominent a place in the romantic movement as French literature and painting. The works of Berlioz represent French musical romanticism in its most complete form. The tendencies in his music were not mere reflections from literature and the other arts, for Berlioz was as independent a factor in the romantic revolt as Hugo or Delacroix. His music was a direct original expression of the general forces which gave birth to the romantic movement, and it shows most of the symptoms of "the disease of the age."

In order to understand the music of Berlioz and the other French romantic composers, it is necessary to study the underlying principles of the general romantic movement. The political and social changes which were a part of the movement found expression in the growing tendency of composers to free themselves from the bonds of patronage, to take a more independent place in society, and a more conscious part in the assertion of national individuality. In philosophic and religious thought, the changes influenced music less directly. The closest affinities between music and the romantic movement are found in a comparative study of music and literature, because the literary romanticists expressed most fully the changes in æasthetic ideas, and also because the leaders in literary romanticism dominated the artistic society of the times. Music is the language of emotion rather than of logic; consequently the changes which influence people's modes of feeling are most important in the consideration of the changes in musical expression. 
It must not be forgotten that the romantic movement was only a background, that music was not merely imitative of literature and the other arts, but had its own independent growth influenced partly by causes which were strictly musical, such as the invention and perfection of new instruments and the development of the sonata form. In considering romantic music in general, therefore, we must take into account both the changes in the society and the life of the times, and those in literature and the other arts, as well as the natural independent progress of the art of music itself.

The romantic movement was primarily a movement of revolt and as Professor Babbitt points out in his Rousseau and Romanticism, must first of all be judged in reference to the conditions from which it revolted. The primary impulse of the movement came as a much needed protest against the conventionality, the artificiality, and the pseudo-classicism of the seventeenth and eighteenth centuries. In the name of natural sympathy and feeling, the romantic movement went to work to break down the barriers of formal restraint which had been thrown up by the preceding generations.

The representative man of the pseudo-classic age was an imitation of a model which had been set up and called "l'honnête homme." He was essentially a creature of restraint and perfect poise; spontaneous enthusiasm was foreign to his nature. His utterances must be dignified. The honnête homme did not follow his feelings but was ruled by decorum, "the grand masterpiece to observe." 1 The favorite epithet for anyone who was original and did not imitate this model set up by society was un monstre-a freak. It was the classic principle of the individual subordinated to the general laws of society, but carried to such an extreme that man became a caricature of his natural self. This period of the ancien régime has been called the "Zopf" or "perruque" period and Carlyle has characterised it as the period of "gigmanity"the respectability of keeping a gig. The court of Louis the XIV was typical of the artificiality of the time.

Nowhere were traditions stronger than in literature. An epic, to attain success, must imitate Virgil, and pseudo-classic literature in general tended to degenerate, not only into an imitation of classic models, but even into an imitation of imitations. Convention limited the writer's vocabulary by rejecting word after word as indecorous. Racine used about one-third as large a vocabulary as Shakspere, and Voltaire condemned Hamlet for 


\section{Background of Romantic Movement in French Music 259}

the line, "not a mouse stirred," because a mouse should not be introduced into tragedy. Tragedy was for the aristocrats, comedy for the bourgeoisie, and farce for the peasants. The structure of the drama was rigidly bound by the unities of time, place, and action derived from Aristotle's poetics, and it was not until the performance of Hugo's Ernani in 1830 that the stage really was freed from the pseudo-classic traditions.

One by one these traditions were destroyed by the leaders of the "enlightenment," Voltaire, Rousseau, Diderot, Condillac, and others of the Encyclopedists. But there is one fundamental difference between such leaders of the "enlightenment" as Voltaire and Condillac, and Rousseau. The first two broke down tradition in the name of reason, the latter in the name of emotional immediacy. The pseudo-classicists had placed reason above emotion, and in his sympathy with this principle Voltaire prolonged classicism. The classic ideas of restraint and of cool rationalism were to continue for a while, even well into the nineteenth century, alongside of the new cult of romanticism. Even when romanticism dominated the intellectual current of all Europe, it would be absurd to conceive of classicism as having disappeared altogether. After all, classicism and romanticism are made up of the same elements only in vastly differing proportions. The pseudo-classicists never entirely excluded emotion nor did the romanticists do away with thought, though at their worst, it must be confessed, they made extraordinary attempts to do so.

In the rise of romanticism, Rousseau was the most gifted and most significant figure. Although much in his theories can be traced back to the English sentimentalism of the early eighteenth century, the original force of his arguments made him the leader in the great battle for the romantic idea. His influence was transmitted through Bernadin de St. Pierre and Chateaubriand to Victor Hugo and George Sand. Spread to Germany it was there reflected and brought back in the writings of Mme. de Staël.

Rousseau stands primarily for emotional individualism. He asserted that science and civilization had led people away from nature, and argued that emotional instinct should be the guiding principle of man's conduct. In order to get back to the natural man, the restraints and artificialities of civilized society must be cast aside. In opposing the classic principle of decorum which had set up a law of restraint for the mere animal impulses, Rousseau asserted that man's natural instincts were good. While the classicist subordinated the individual to the laws of society, 
the sens propre to the sens commun, Rousseau exalted the law of individuality. Pater has quoted the opening lines of Rousseau's Confessions as representative of the whole romantic movement. "I am different from all men $I$ have seen. If $I$ am not better, at least I am different."

This emphasis on emotional individualism led to a revival of the poetry of passion, stimulated an interest in nature, and inspired a spiritual renaissance which was to find its culmination in the writings of Chateaubriand. Now, to no art could emotionalism mean so much as to music. Consequently it is this aspect of the romantic movement which was most important in its influence on the development of music. That music did not respond sooner to the wild note of revolt against traditions for the sake of emotion, was chiefly because music in the eighteenth century was in such a transitional stage of technical development. But, as the "language of the emotions," it was bound sooner or later to be a protagonist in a movement of which one of the principal tenets was the exaltation of emotion over reason.

The change from the social and political conditions of the eighteenth century to those of the nineteenth was marked by no less an upheaval than the French Revolution. It was a revolt from extremes of autocratic government, and it strove to release a new freedom of thought in social, political, and religious affairs. The shackles of aristocratic government were broken in the name of universal fraternity. The culmination of the French Revolution in irrational imperialism, ${ }^{1}$ the opposite of the object for which it set out, does not disprove the cause for its initial impulse. In emphasizing the freedom of the individual, the revolutionists placed the "sympathetic rebel" on a pedestal. The crimes of the outlaw were pardoned because society and not the outlaw was responsible for them. Schiller was made an honorary citizen in the French Republic out of admiration for his play, Die Räuber, in which the chief character is a brigand, with a "beautiful soul," who has been forced into his profession by the conditions of a false society. In music the revolutionary spirit of the age was shown in the altered relations of composer to patron. Haydn had held but a servile position at the court of Prince Esterhazy, but Beethoven, oniy a few years later, was able to take a free and independent place in the social life of Vienna.

It is, however, an illusion to think that political freedom means freedom of thought. Nothing was more obstructive to the development of romantic art and literature than the dead level of 
the bourgeois point of view of the First Republic. The bourgeois mind could not see beyond the material present and had no conception of the relation of art and literature to life. In England, Carlyle and Mathew Arnold fought the "philistines." In musical history we think of Schumann with his "Davidsbundler contre les philestins" and Berlioz with his tirade in Lelio against the despoilers of art.

To many in France the reign of reason meant the substitution of science for religion. A mechanistic theory of life came to take the place of the exploded absurdities of religious belief. Some merely exchanged the slavery of pseudo-classicism for the slavery of agnosticism. But there were others, philosophers, scientists, socialists, and priests, who looked below the surface currents of the time and tried to make an adjustment and reconstruction of philosophic ideas, not forgetting the past and with a view to the future. Such were Saint-Simon, Fourier, Lamennais, Ballanche, and Auguste Comte, who, says Emile Faguet, in speaking of this whole group, did not think "que ce fat purement et simplement un des anciens pouvoirs spirituels qu'il fallait rétablir tel qu'il avait été; mais qu'on devait restaurer l'un ou l'autre des anciens pouvoirs spirituels sous une forme nouvelle et avec un nouvel esprit."' The fact that Saint-Simon, in his allembracing scheme of philanthropic religion with its ideas of social equality, popular education, and moral freedom, placed music with the other arts as one of the chief means for spiritual uplift, did much to encourage musicians to take a more áctive and dignified part in the social and artistic life of their times. In general, however, the relation of music with politics, philosophy, or religion was indirect rather than direct. It seems from the nature of the art of music that it must always be so. We can at least say that whatever in philosophy or religion tended to explain or express the spiritual nature of man, found in romantic music a powerful ally.

Returning to the development of romanticism in literature, we find Mme. de Staël and Chateaubriand as the two most prominent figures at the opening of the nineteenth century. They were practically the founders of the romantic school in French literature.

Rousseau had been the object of Mme. de Staël's early admiration and her first literary work was the Lettres sur J.-J. Rousseau in 1788. Her more important works were her Littérature, which appeared in 1800, and her Allemagne, the entire first French edition of which was destroyed by order of Napoleon. She was

'Faguet: Politiques et Moralistes du 19 sizcle. 
Swiss herself but of mixed heredity. It is said that she had a French head and a German heart. Her two visits to Weimar and her intimacy with Friedrich Schlegel, who, for some time, was a tutor in her family, explain her special preoccupation with the romantic movement in Germany. It was she who connected the streams of thought which were flowing in more or less parallel lines in France and Germany. Goethe, who, at the time of her visits to Weimar, felt a national antipathy for her, later said that she broke a large gap in the Chinese wall which separated Germany from France and the rest of Europe. She brought into France the nebulous romanticism of the North,-the "septentrional" idea that depth and seriousness are the distinctive characteristics of the people of northern countries. She believed in the efficacy of that melancholy which found, to her mind, its most perfect expression in German thought. Stimulated by Rousseau toward universal sympathy, and moved by an insatiable intellectual curiosity, her horizon took in the literary and social activities of all Europe. Her enthusiasm inspired renewed interest in lyricism, art, religion, criticism, and philosophy. Representing, as she does, the broadening mind of the time, free from all conventionality of thought, she stands preeminently for intellectual cosmopolitanism.

Chateaubriand's importance, was national rather than international. He exerted a great influence on French literature by giving fluent and beautiful expression to the emotional ideas originated by Rousseau. "Mme. de Staël thought and taught other people how to think. Chauteaubriand felt and taught other people how to feel." Religion, like everything else in life, appealed to him esthetically. He cultivated emotion. He had the romantic desire to feel and suffer uniquely, and there is an ever increasing egoism in the expression of his melancholy. René is the story of unhappiness caused by hidden, indefinable longings; all the young men of Chateaubriand's time were led to imagine themselves Renés. Lasserre" remarks that, "Dégagé de son orchestration, le thème de René est bien le thème d'Adolphe; vide, ennui, impuissance à participer aux émotions naturelles de l' homme, à entrer dans le cours commun de la vie, perpétuel appel de la sensibilité desolée à la passion." Melancholy was the universal malady and it was nearly always an extremely self-cultivated melancholy. The sincere romantic longing of Senancour in literature and of Chopin in music, was exceptional and in strong contrast to Chateaubriand's morbid nostalgia. 


\section{Background of Romantic Movement in French Music 263}

Where Chateaubriand excelled all other writers was in the marvellous picturesqueness and color of his descriptive style and in the lyric beauty of his language. Travel in many foreign countries including the wilderness of America, provided him with inexhaustible material for his art. Picturesqueness rather than accuracy, color rather than clear outline, made his pictures live vividly in the imagination. He luxuriated in the color suggestiveness of language and developed the grand orchestra of words as Berlioz later created the grand orchestra of musical sounds. He was a poet who wrote in prose. The remarkable outburst of romantic lyric poetry was largely due to the stimulus which his works gave. The exquisite lyricism of Chateaubriand was reflected in the music of Liszt, his picturesqueness and brilliant color in the great orchestral compositions of Berlioz. The dwelling on what was local and different in one person or place from another, was a distinctly romantic trait. The classicist constructed his philosophy from what was common and fundamental in life and nature; the romanticist sought after the unusual and fell into exoticism and orientalism. Romantic art had to add "strangeness to beauty." David's Le Desert was only one of the most sensational examples in music of the romantic interest in the Orient, and we think of the whole nineteenth century in music as the time when local color became one of its most vital qualities.

After Mme. de Staël and Chateaubriand, the romanticists became a recognized literary party and romanticism a cult, through which the romantic tendencies were often exaggerated into caricatures of their original forms. Poets competed with one another to show the intensity of their sufferings. Musset drew the image of a pelican feeding her.young from her own flesh. Each poet imagining himself alone in the world withdrew into his "ivory tower." Yet this solitude was not one of silence, for the romanticist could not resist telling the world of his unique and utter loneliness. Each one wanted to live in a "hermit's cell on the stage." To egoism was added eccentricity. In fact the whole movement was eccentric in the sense that all these tendencies led away from the classic, concentric, conception of art as representing feelings which are common to human nature, rather than peculiar to an individual. Cutting loose from the old connections with mankind the romanticists found themselves isolated and lonely with nothing to substitute for what they had lost. Lasserre, in his extremely anti-romantic Le romantisme français, considers all this later period as the decadent sequel of the real romantic movement, which had ended with Mme. de Staël and Chateaubriand. 
The emotional intensity of the romantic cénacle was not, however, all wasted in exaggerated posturing, but expressed itself in a marvellous outburst of lyric poetry in the works of Lamartine, Hugo, Vigny, and Musset. Of these, Vigny is the most philosophical and his poetry is the most lasting. He had more of the stoic in his nature and did not exaggerate the sensitiveness of his feelings. Musset, on the contrary, exhibited all the pain of his wounded heart. Lamartine was more optimistic. In romantic poetry there is the effort to substitute for real religion a religion of beauty, of science, of nature, of love, or of humanity. Each in turn proves an illusion and the poet is left uncomforted in his suffering solitude. In the work of all these poets there are qualities which are clearly paralleled in music, their subjectivity, their melancholy, and their freedom from restraint. The romantic poets also show a free, revolutionary attitude toward the traditional forms of their art exactly as did Berlioz, Liszt, and Chopin. Lamartine's trait of poetic improvisation is seen in the Années de.Pélérinage of Liszt, and the spontaneous lyricism of all romantic poetry finds complete expression in the music of Liszt and Chopin.

Hugo and Vigny led the way in the sensational revolution in the drama. Here there was a more radical breaking down of the traditions. The classical conventions of the drama had shown a particular strength in withstanding the assaults of the revolutionary spirit. It was not until Hugo's Ernani in 1830 that the romanticists really obtained possession of the stage, but the breaking down of the conventions then was all the more ruthless. The one rule of the new drama was to mirror life. Decorum was banished and the wildest and weirdest scenes were portrayed without restraint. The romanticists wanted strong emotions with no squeamishness as to how the emotions were produced. In the search for thrills they forgot the dignity of tragedy. They forgot, when they portrayed "the saturnalia of a mother's grief," that restrained feeling is more powerful than unrestrained feeling. The revolutionary spirit is bound to go to extremes, particularly when the fray is at its hottest, as it was at the première of Ernani. The romantic poets, artists, and musicians who rallied around the banner raised by Hugo in 1830 were as radical as could be any army of political revolutionists, and the victory which they gained through the success of Ernani only led them into wilder extravagances.

Of other spirits in the literary romantic movement, George Sand requires special notice for her connection with romantic musicians, particularly Liszt and Chopin. She, herself, went through all the phases of the romantic movement. She was the 
romantic Titaness. In her own words, after her youth had come to an end in "convulsions and groans," she became "plunged in the ideas of socialism." She wore men's clothes and smoked. She professed passion and made a religion of love. Her early works helped to undermine whatever ideas of conventional morality had been left to the young men of the time. Her mind was essentially subjective, and her novels were as lyrical in sentiment as romantic poetry.

In French painting the romantic revolution was as upsetting as in literature. At the beginning of the century there had been a revival of classicism under David, but it could not stem the rising tide of the romantic desire for freedom from traditions. David himself had rebelled from the embellished style of the rococo and the fashionable furbelows of Boucher and Fragonard, but, though he professed to paint entirely from nature, he unfortunately could not look at nature save in the light of Græco-Roman æsthetics. In seeking the conventionalized forms of antique statuary he eliminated movement from his art. His heroes pose and never act. In the paintings of Delacroix, the preeminent exponent of romanticism in French painting, action and color are the distinguishing characteristics. Romantic painters drew their inspiration from the Middle Ages, from modern history, and from the Orient rather than from classical mythology. Delacroix had been preceded by Géricault, who died before romanticism had actually declared war on classicism, but whose Raft of the Medusa belongs clearly to the romantic school. The distorted, starving figures crowded on the shipwrecked raft represent a horrible picture of human suffering. The very degree of distortion of the human body and the way detail is piled on detail points directly to the excesses of the romantic imagination. Yet it was not until Delacroix's Massacre of Scio that the academic critics began to talk about the "massacre of painting." Delacroix loaded his palette with brilliant colors and painted with the unrestrained vigor of a revolutionist. He hated straight, wavy, and especially parallel lines, and tried to make his painting turbulent and rough,- it was called painting of a "drunken brush." It had the main romantic traits of disregarding tradition and emphasizing individual emotion. Gautier says that Delacroix "responded more than anyone else to the fever of his epoch." Gautier also says, "Dans son œuvre, Delacroix a toujours cherché le signe caractérisque, le trait de passion, le geste significatif, la note étrange et rare."

At this particular period, poets and artists belonged to the same romantic brotherhood. The artists read the poets and the 
poets visited the artists. Shakespeare, Dante, Goethe, Byron, and Scott were found as frequently in the atelier as in the study. Deveria, from whom much was hoped by the advocates of romantic painting, distinguished himself by the frenzy of his applause at the tumultuous performance of Hernani, where he led a band of artists and students.

The influence of Rousseau was not limited to France but extended over the whole of Europe. In Germany the "Sturm und Drang" period of the end of the eighteenth century was followed at the beginning of the nineteenth, by one of the most extraordinary ebullitions of the romantic movement. The romantic school in Germany was characterised by a hopeless confusion of genres and of ideas. Someone has said that studying the romantic movement in Germany is like running into a fog bank. It was marked by an excessive use of symbolism and weird fantasy. The fantastic element was especially marked in the works of E. T. A. Hoffmann, who became very popular in France, through translations, in the 1820's. The characters of his weird tales were so grotesque that Hoffmann was accused of being either insane or under the influence of opium. In him German romantic literature and music were brought into connection one with the other. He was a well-known composer as well as a story-teller and critic, and one of the leading exponents of the theory of music as the ideal romantic art.

This idea was common among the German romanticists from Wackenroder and Jean Paul Richter to Tieck and Hoffmann. They all harped on the theory that romantic literature should strive to attain the suggestive, indefinite quality of music. It is one of the most striking differences between French and German romanticism, that in France the boundaries of the different arts never became so confused as in Germany. In some ways, of course, the German conception of music as inherently the most romantic of the arts, brought the literary movement there into even closer touch with the romantic movement in music. But after all, romanticism in music does not depend upon the æsthetic theories of poets, but upon the inspiration of composers influenced by romantic ideas.

Music in Germany was, moreover, more intimately connected with the life of the people than in France. That is the reason why Romain Rolland has called the Germans a more musical race than the French, much to the chagrin of his compatriots. He does not say that the Germans have more musical discrimination, but merely acknowledges the fact that music has grown in Germany to be an integral part of the national life, from peasant to noble, as 
it has never been in France. It was partly a result of the democratic status of music in Germany that it there soon broke away from the conventionalities of Italian opera.

German tendencies both in music and literature strongly affected the course of the romantic movement in France. In music the influence was exerted through the performances of the works of Haydn, Mozart, Beethoven, and Weber. Knowledge of particular phases of German literary romanticism was spread through the writings of Mme. de Staël. Schlegel's Vorlesungen über dramatische Kunst und Litteratur were translated into French in 1814, and before 1830, translations of many of the most important works of the German romantic school had appeared including two versions of Faust. The general influence of German romanticism in France both in music and in literature was in developing the qualities of poetic imagination and fantasy.

From England came the influences of Scott and Byron. Both were read tremendously in translation and in the original. Scott's influence joined with Chateaubriand's in stimulating the historical and pictorical imagination, and in emphasizing picturesqueness and local color. His stories were like the large luxuriantly colored canvasses of the romantic painters. Byron was more radically and powerfully revolutionary in sentiment, and consequently more truly romantic. Byron was a superman with an irresistible instinct for revolt against everything. Goethe said that he showed no respect for any law, human or divine, except the law of the three unities. He was considered the supreme example of romantic despair and haughty isolation, theatrically conceived. The famous lines of Matthew Arnold from The Grand Chartreuse picture him perfectly.

\author{
What helps it now, that Byron bore, \\ With haughty scorn that mock'd the smart, \\ Through Europe to the Aetolian shore \\ The pageant of his bleeding heart? \\ That thousands counted every groan, \\ And Europe made his woe her own?
}

He played an important part in the rise of romantic socialism though his works did not appeal particularly to real social theorists like Saint-Simon, Fourier, Pierre Leroux and Prudhomme.

In studying the tendencies of the romantic movement which either found expression in music or influenced its course, it is interesting to note that the leaders of the romantic movement in France, generally speaking, gave little thought to any peculiarly romantic quality in music and felt no special sympathy with the 
art. The literatures of all countries contain a number of stock phrases in which music is referred to metaphorically, -as the "music of the spheres" or "of nature." From Plato down to the present day, music has been used in a vague and indefinite way to explain or supplement ideas of philosophy, religion, art, and even science. Burton in the Anatomy of Melancholy spends much space in explaining Music, a Remedy. This sort of thing is generally quite superficial and has had no important relation to the progress of music. On the other hand, there have been writers, like Browning or Balzac, whose use of musical subjects and musical similes, based on real technical knowledge, help at least in the study of certain psychological aspects of music. There have been still others, like Jean Paul and E. T. A. Hoffmann, whose conceptions of the functions of music must be taken into account in the historical study of the evolution of the art.

Of the leaders in French romanticism only a few showed any decided interest in music. Rousseau again stands out as an anticipator of romantic developments in music. He, himself, was a composer of no mean ability, though his conception of the powers of music soared far beyond his powers of musical creation. His Pygmalion, in which music alternates with words, is a curious attempt to solve the operatic problem. Le Devin du village, an intermède, in one act, held the stage for three quarters of a century. But it was Rousseau's theory of music which was important. He had extraordinary insight into the nature and effect of music. In his Essai sur l'origine des langues, published after his death, he wrote, "sleep, stillness of night, loneliness, even silence, may be painted by music. The composer will not present such scenes directly but he will call up in our souls the same impressions which we receive from the real scenes." Again he expressed the main argument of all harmonic revolutionists when he said, "What is pleasurable to the ear is the result of custom." This statement is taken from an essay by Rousseau entitled, Examen de deux principes avancés par M. Rameau dans la brochure intitulee: Erreurs sur la musique dans l'Encyclopédie. Though not published until 1764, it was nine years earlier, in 1755 , that Rousseau had written this defense of the articles on music which he had contributed to the great encyclopedia of Diderot and d'Alembert. Rousseau had had the most haphazard musical education and, though he had done considerable reading in preparing these musical articles for the encyclopedia, in comparison with Rameau he was anything but a well-grounded musician. Yet this extraordinary man seemed to have the same instinct for recognizing the fundamental principles 


\section{Background of Romantic Movement in French Music 269}

of the art of musical expression that he had shown in writing about the social and political questions of the day, and with as little real knowledge on which to base his reasoning.

The two main assertions of Rameau, ${ }^{1}$ contradicted by Rousseau in the essay mentioned above, are, that melody is less important than harmony from which it is derived, and that "the fundamental essential of music, as of all arts and sciences, is proportion." This second assertion represents that objective attitude on the part of the composer which values beauty of design and form more than emotional expression and which decrees that these qualities must be attained by following certain definite models and standards. It is the attitude which emphasizes decorum, the sense of what is right and wrong according to established conventions. It was from just such ideas in life and art that Rousseau revolted. Above everything else he prized the spontaneity of genius. The "original genius" of Rousseau was a genius freed from the restraints of conventionality and custom, whose individual inspiration was the only guide for his method of musical expression.

The controversy between these two representative men of the eighteenth century reflects the general contest between form and imagination as the controlling element in art. When Rousseau defined the object of music as the reawakening of emotions previously experienced in real life, did he not enunciate the principle which underlies the programmistic tendencies of nineteenth century music?

No one, until Balzac, comprehended so clearly as Rousseau the romantic possibilities of music. The cosmopolitan Mme. de Staël gave little thought to music in spite of the fact that music has been so frequently called the "universal language." Chateaubriand, too, whose use of words is so preeminently musical, had little sympathy for the art of music itself. Lamartine called music "the literature of the heart," and he seems to have recognized the romantic attribute of music-its indefiniteness. This was the peculiar quality of his own poetry. Trying to describe an ideal language, he said that it should be "vague, éclairé, flamboyant, caressant comme des langues de feu." Lamartine found in the music of Liszt's improvisations the perfect medium for the expression of the infinite, and of the indeterminate longing of the romantic soul. He influenced Liszt in developing in music free-

\footnotetext{
Rameau: Observations sur notre instinct pour la musique et sur son principe; ou les moyens de reconnaitre l'un par l'autre conduisant d pouvoir so rendre raison aveo certitude des différens effets de cet art.
} 
dom of expression, as against formality. Musset and Sand had more than the average sympathy for music without, however, understanding its romantic possibilities. Hugo's interest as shown in the seven stanzas of Que la musique is only the superficial interest of poets in borrowing the symbolism of musical terms.

Balzac, on the other hand, demonstrated in Gambara, Massimilla Doni, and other works, his keen understanding of music and the psychology of the musician. In Gambara there is the conception of music as an intensely expressive and descriptive language. Balzac understands and explains the efforts of romantic composers to get away from colorless conventionality, from meaningles designs, and to make music more descriptive of special moods and situations. He adopts in Gambara the fantastic idea of music that we find in Hoffmann's Kater Murr. Gambara is a second Kreisler, a creature entirely at the mercy of his ungovernable artistic temperament. It is but the exaggeration of the "original genius" idea of Rousseau, and is true to the musical life of the day. It seems as if Gambara must have been drawn from Berlioz and with a foreknowledge of Wagner and Richard Strauss. Balzac's writings took an active part in spreading the gospel of musical romanticism.

Saint-Simonianism affected the position of music in society, in that it exalted music as one of the chief means to general cultivation. Liszt was much influenced by this attitude of the SaintSimonians towards music.

The general tendencies of the romantic movement spread particularly rapidly to music on account of the growing intimacy between musicians and other artists. The friendly intercourse may be noted here of Berlioz, Liszt, and Chopin, with Hugo, Musset, Sand, Balzac, Lamennais, and Delacroix.

In French romantic literature, in sharp contrast to German literature as has been shown, there was little inclination to distinguish music as the most romantic of the arts. It was partly because French poets did not feel that, in order to express the infinite, all definiteness of expression must be lost and only suggestion and impression left. The indeterminate longing, "le vague des passions," was certainly a strong element in French romantic thought, but the French romanticists never lost themselves in quite such a misty philosophy as the Germans. Then again, the French instinct for the genres tranchés took for granted the limitations of the different arts and avoided the confused mixture of poetical and musical symbols in German romantic poetry. 
The fundamental romantic tendencies have been noticed in the foregoing survey of the general romantic movement. It was noted at the start that those changes in thought which had an resthetic rather than a political significance would naturally find a more definite expression in an art which is primarily a language of emotion rather than of thought. The chief cause for the rise of the romantic spirit was found in the revolt from the extreme formality of the pseudo-classic epoch. Consequently the revolutionary spirit which upsets and disregards traditions is everywhere apparent. Rousseau stood for the exaltation of individual emotionalism over rationalism. From this grew the tendencies towards lyricism, egoism and eccentricity. Chateaubriand's emphasis on picturesqueness and color led to the cult for the strange and the exotic. "Le vague des passions" grew into the malady of the age, egoistic melancholy and romantic nostalgia. The fantastical tendency of the romantic school in Germany and the rebellious trend of the Byronic cult, added their forces to the growing current of romanticism in France. 